\title{
REFRAKSI DAN DIFRAKSI GELOMBANG LAUT DI DAERAH DEKAT PANTAI PARIAMAN
}

\author{
Itto Samulano ${ }^{1}$, Mas Mera ${ }^{2}$
}

\begin{abstract}
ABSTRAK
Penelitian ini menitik-beratkan pada simulasi penjalaran gelombang laut di daerah dekat Pantai Pariaman dengan memperhitungkan proses refraksi dan difraksi. Simulasi ini dilakukan secara numeris menggunakan program RCPWave (persamaan pengaturnya adalah mild-slope equation) dengan empat program pendukung, yaitu Grid Generation untuk mengolah data bathymetry, DinaHindcasting untuk mengolah data angin, WWWL Data untuk menyusun keluaran program DinaHindcasting, dan WMV untuk menampilkan keluaran program RCPWave sehingga menghasilkan vektor (arah dan tinggi) gelombang. Kelima program tersebut adalah program yang telah jadi (existing computer softwares). Domain model adalah sepanjang Pantai Pariaman, dimulai dari Pantai Padang Birik-Birik di utara sampai Pantai Sunur di selatan yang berjarak $14 \mathrm{~km}$ dan ke arah lepas pantai sejauh 13,50 km. Dalam domain terdapat lima buah pulau-pulau kecil (Pulau Kaciak, Angso, Tangah, Ujung, dan Pulau Sibarat). Parameter gelombang yang digunakan dalam simulasi ini adalah data angin sepanjang tahun 2010 dan peta bathymetry, tetapi sudut datang gelombang dibuat bervariasi. Hasil simulasi menunjukkan bahwa refraksi dan difraksi gelombang paling besar terjadi di samping kiri semua pulau-pulau. Pada sudut datang gelombang $45^{\circ}$ (terhadap garis tegak lurus pantai), pembelokkan gelombang terbesar adalah $98^{\circ}$ terjadi di dekat Pulau Kasiak, sehingga tinggi gelombang di lokasi ini lebih kecil dari tempat lain. Sementara itu, tinggi gelombang yang besar terjadi di depan semua pulau dan dekat garis Pantai Pariaman karena pengaruh pendangkalan. Arah gelombang di dekat sepanjang garis Pantai Pariaman hampir membentuk sudut tegak lurus dengan garis pantai, kecuali pada pantai di Padang Birik-Birik, Pauh Barat dan Taluak.
\end{abstract}

Kata Kunci: refraksi, difraksi, sudut gelombang, tinggi gelombang, Pantai Pariaman.

\section{PENDAHULUAN}

Faizal (2002) telah melakukan simulasi numeris tentang pengaruh refraksi dan difraksi terhadap perjalanan gelombang laut menuju Pantai Kuta, Bali menggunakan perangkat lunak yang telah jadi, REF/DIF. Model numeris REF/DIF ini dikembangkan oleh Kirby dan Dalrymple sejak tahun 1982 menggunakan metode beda hingga dengan persamaan pengatur yang mengkombinasikan efek refraksi dan difraksi gelombang untuk topografi dasar laut yang landai.

Pada tahun 2005, Zein dan Tarigan melakukan analisis refraksi gelombang laut dekat pantai menggunakan empat metode, yaitu metode ortogonal, metode Snellius, metode diagram dan metode panjang gelombang. Keempat metode ini pada dasarnya mengacu pada teori gelombang linear atau teori gelombang amplitudo kecil (small-amplitude wave theory). Uraian rinci tentang teori gelombang ini dapat dilihat pada Dean dan Dalrymple (2000). Hasil yang diperoleh dari tiap metode menunjukkan hasil visualisasi sudut pembelokkan gelombang yang cukup baik untuk digunakan dalam memahami refraksi gelombang. Namun terdapat keterbatasan pada tiap-tiap metode. Pada metode ortogonal terdapat keterbatasan nilai perbandingan kecepatan gelombang pada template sehingga penggambaran refraksi tidak dapat dilakukan untuk nilai perbandingan kecepatan gelombang yang relatif besar. Pada metode Snellius terdapat nilai beda sudut perpindahan gelombang yang cukup kecil sehingga sulit untuk memvisualisasikan hasil refraksi

\footnotetext{
${ }^{1}$ Ex Mahasiswa Jurusan Teknik Sipil Universitas Andalas, itto_samulao@ymail.com

${ }^{2}$ Dosen Jurusan Teknik Sipil Universitas Andalas, masmera@ft.unand.ac.id
} 
dibandingkan dengan metode ortogonal. Metode panjang gelombang, walaupun sulit untuk menggambarkan refraksi gelombang, tetapi memiliki kelebihan dalam penggunaan yang tidak terbatas untuk pantai yang mempunyai kontur lurus dan sejajar.

Hutahean (2008) mengembangkan sebuah model numeris yang dapat mensimulasikan refraksigelombang laut karena bathymetry, serta shoaling dan breaking berdasarkan persamaan arah gelombang (atau persamaan refraksi-difraksi) dan persamaan amplitudo gelombang. Kedua persamaan tersebut dirumuskan menggunakan persamaan kontinuitas dan momentum. Model numeris ini kemudian digunakan untuk mensimulasikan refraksi-difraksi gelombang pada teluk dan tanjung sehingga terbentuk penyebaran energi pada teluk dan pengumpulan energi pada tanjung.

Pada tahun 2009, Baharuddin dkk melakukan penelitian tentang pola transformasi gelombang di daerah dekat Pantai Bau-bau, Provinsi Sulawesi Selatan menggunakan model RCPWave. Pantai Bau-bau terdiri dari pantai yang menghadap ke barat (pantai barat) yang lebih terbuka (laut bebas) dan pantai yang menghadap ke timur (pantai timur) yang semi terbuka (Teluk dan Selat Buton). Hasil model ini menunjukkan bahwa bahwa tinggi gelombang pecah mencapai 1,0 $\mathrm{m}$ di daerah tanjungnya.

Riyaldi (2010) memodelkan refraksi gelombang di perairan dangkal di Tegal Jawa Tengah menggunakan model numeris yang telah ada SWAN (Simulating Wave Nearshore). Pantai yang dimodelkan adalah pantai yang mempunyai jetty dengan kemiringan 0,01, 0,03 dan 0,05. Hasil model menunjukkan pola lokasi gelombang pecah dan pengaruh jetty terhadap tinggi dan arah penjalaran gelombang, sehingga hasil model ini dapat dipakai sebagai bahan kajian tentang efektifitas pemasangan jetty di Pelabuhan Tegal terhadap tinggi dan arah gelombang.

Penelitian sekarang ini adalah melakukan simulasi numeris refraksi dan difraksi gelombang menggunakan model RCPWave seperti yang dilakukan Baharuddin dkk (2009), tetapi untuk laut dekat Pantai Pariaman di Provinsi Sumatera Barat sebagai pengganti Pantai Bau-bau di Provinsi Sulawesi Selatan. Transformasi gelombang yang dibahas adalah refraksi dan difraksi. Penjelasan rinci tentang transformasi gelombang ini dapat dilihat pada Samulano (2012) dan SPM (1984).

\section{DOMAIN MODEL}

Simulasi penjalaran gelombang di daerah dekat Pantai Pariaman ini dilakukan dengan menggunakan existing software RCPWave (Regional Coastal Processes Wave Propagation Model). Sebuah model numeris menggunakan metode beda hingga 2 dimensi (2D) untuk menyelesaikan persamaan pengaturnya. Model ini dikembangkan oleh Bruce A. Ebersole, Mary A. Cialon dan Mark D. Pratt dari Coastal Engineering Research Center (CERC), US Army Engineer Waterways Experiment Station pada tahun 1986.

Model RCPWave ini dibantu oleh empat buah existing software pendukung, yaitu: (1) Program Grid Generation untuk mengolah data batimetri dan garis pantai yang menghasilkan file masukkan bagi RCPWave; (2) Program Dina-Hindcasting untuk mengolah data angin yang menghasilkan data periode, tinggi dan sudut datang gelombang; (3) Program WWWL Data untuk menyusun keluaran program Dina-Hindcasting; (4) Program WMV untuk menampilkan keluaran program $R C P$ Wave dalam bentuk vektor gelombang (arah dan tinggi gelombang) (CEDAS, 2004a, 2004b).

Domain yang diambil adalah Pantai Pariaman dengan sudut datang gelombang yang dibuat bervariasi seperti yang ditunjukkan Gambar 1. Sudut datang gelombang ditentukan berdasarkan stabilitas komputasi program RCPWave. Perbandingan jarak grid pada sumbu-y (DY) dan jarak grid pada sumbu-x (DX) atau DY / DX yang digunakan pada penelitian ini adalah 1, dengan nilai DY dan DX sebesar $15 \mathrm{~m}$. Konsekuensinya, sudut datang gelombang dibatasi sampai $45^{\circ}$ terhadap

\section{J URNAL REKAYASA SIPIL}


garis tegak lurus pantai. Maka, domain model pada perairan Pantai Pariaman dimulai dari sudut $-45^{\circ}$ sampai $45^{\circ}\left(0^{\circ}\right.$ merupakan sudut datang gelombang yang tegak lurus terhadap garis pantai). Panjang domain arah sumbu-x adalah 13500 m, sedangkan panjang arah sumbu-y adalah $14000 \mathrm{~m}$ yang dinyatakan sebagai garis yang sejajar garis pantai. Perbandingan panjang sumbu-x dengan DX sebesar 900 dan perbandingan panjang sumbu-y dengan DY sebesar 933,33 (batasan RCPWave untuk perbandingan panjang sumbu dengan panjang grid dibawah nilai 1000).

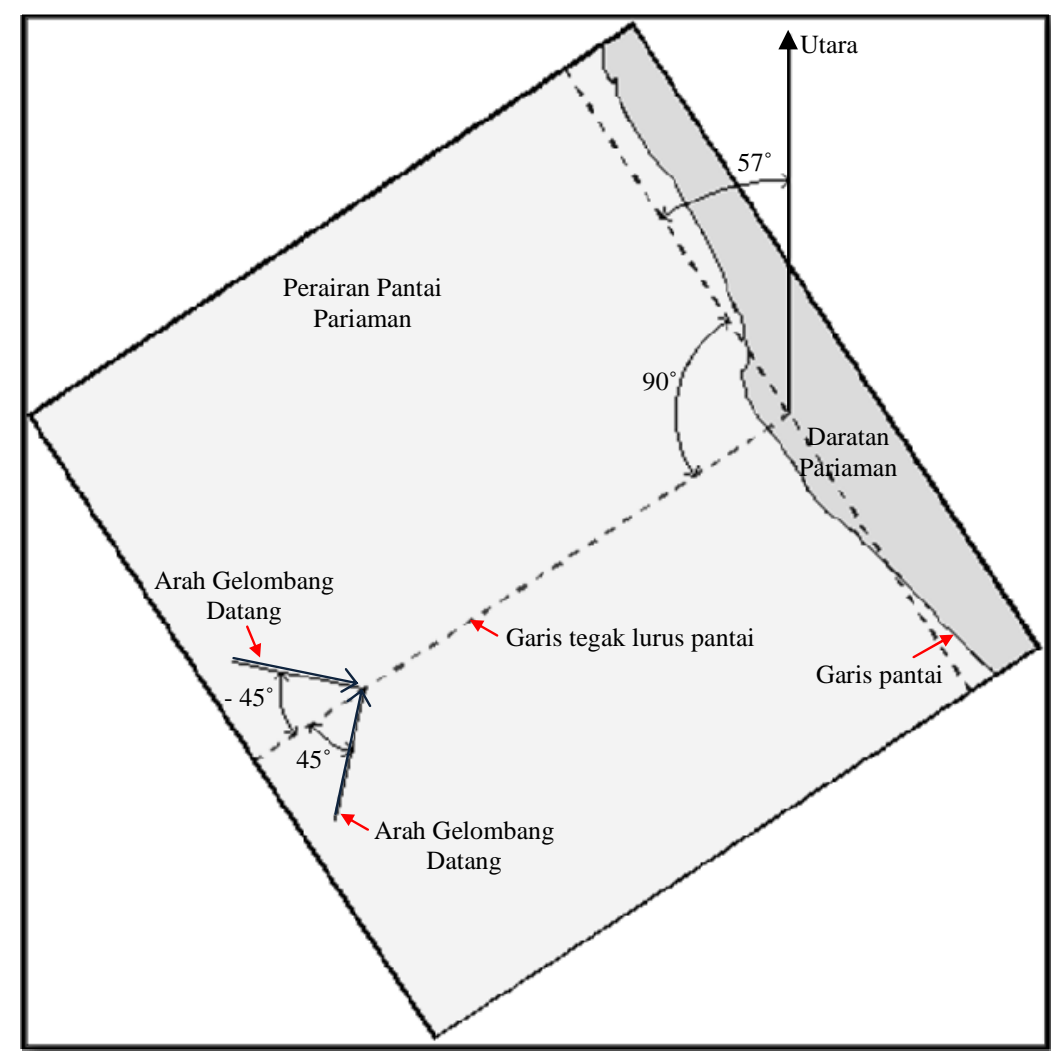

Gambar 1. Domain

Data periode gelombang (T) yang digunakan adalah data yang diambil dari data angin (arah dan kecepatan) selama tahun 2010 yang bersumber dari Badan Meteorologi, Klimatologi, dan Geofisika (BMKG) Ketaping Padang Pariaman yang kemudian diolah dengan program DinaHindcasting (Fajra, 2011). Data batimetri Pantai Pariaman diperoleh dari Peta Ekosistem / Padang / Lembar 0715 pada Proyek Pengelolaan Sumberdaya Pesisir dan Laut dilakukan oleh Marine \& Coastal Resources Management Project (MCRMP) bekerja sama dengan Badan Perencanaan Pembangunan Daerah (BAPPEDA) Pemerintahan Provinsi Sumatera Barat tahun 2004. Data batimetri yang digunakan dari kedalaman 0 m sampai kedalaman 100 meter.

\section{POLA TRANSFORMASI GELOMBANG DENGAN SUDUT DATANG $-45^{\circ}$}

Hasil simulasi gelombang dengan sudut datang $-45^{\circ}$ terhadap garis tegak lurus pantai diperlihatkan pada Gambar 2. Pada Pulau Kasiak (A), gelombang yang melewati samping kanannya mengalami pembelokkan sebesar $138^{\circ}$ ke arah pantai, $128^{\circ}$ ke arah sejajar belakangnya, dan gelombang yang melewati samping kiri pulau ini mengalami pembelokkan sebesar $154^{\circ}$ ke arah sejajar belakangnya. Di Pulau Angso (B), gelombang yang melewati samping kanan pulau ini 
membelok sebesar $160^{\circ}$ ke arah pantai, $143^{\circ}$ ke arah sejajar belakang pulau dan gelombang yang melewati samping kirinya mengalami pembelokkan sebesar $154^{\circ}$ ke arah sejajar belakang pulau ini. Di sekitar Pulau Tangah (C), gelombang yang melewati samping kanan pulau ini mengalami pembelokkan sebesar $151^{\circ}$ ke arah pantai, $109^{\circ}$ ke arah sejajar belakangnya dan gelombang yang melewati samping kirinya membelok sebesar $162^{\circ}$ ke arah sejajar belakangnya. Pada Pulau Ujung (D), gelombang yang melewati samping kanan pulau ini mengalami pembelokkan sebesar $154^{\circ} \mathrm{ke}$ arah pantai, $125^{\circ}$ ke arah sejajar belakang pulau ini. Gelombang yang melewati samping kiri pulau ini mengalami pembelokkan sebesar $149^{\circ}$ ke arah sejajar belakangnya. Di Gosong Sibarat (E), gelombang yang melewati samping kanan gosong mengalami pembelokkan sebesar $155^{\circ}$ ke arah pantai, $135^{\circ}$ ke arah sejajar belakang gosong. Gelombang yang melewati samping kiri gosong mengalami pembelokkan sebesar $173^{\circ}$ ke arah sejajar belakang gosong.

Pada saat melewati samping kanan pulau-pulau, sebagian gelombang ada yang berbelok dan berusaha sejajar dengan garis pantai di belakangnya, sebagian ada yang berusaha tegak lurus terhadap arah pantai dan sebagian lagi ada yang cenderung ke arah selatan. Sedangkan pada saat melewati samping kiri pulau-pulau, sebagian gelombang ada yang berbelok dan berusaha sejajar dengan garis pantai di belakangnya, dan sebagian lagi terus merambat ke arah selatan yang akhirnya bertemu kembali dengan gelombang dari arah samping kanannya, tepatnya disebelah kanan pada belakang pulau-pulau tersebut.

Perambatan gelombang ini terus melaju mendekati pantai dan cenderung untuk tegak lurus terhadap garis kontur dasar laut sampai mendekati pantai, karena adanya pendangkalan pada dasar laut dekat pantai.

Perairan yang memiliki pulau-pulau kecil tersebut mengalami refraksi dan difraksi gelombang paling besar terjadi pada saat melewati samping kanan pulau. Adanya pembelokkan tajam dan penyebaran arah gelombang sebanyak tiga arah, yang disebabkan oleh sudut datang gelombang, sehingga pembelokkan gelombang pada samping kanan pulau membentuk sudut yang lebih kecil dari pada samping kiri pulau. Selain itu kerapatan batimetri juga mempengaruhi pembelokkan gelombang sehingga gelombang berusaha sejajar dengan garis pantai di belakang pulau. Karena semakin rapat batimetri, maka semakin cepat terjadinya proses pembelokkan (refraksi) di dekat pantai pada pulau-pulau tersebut.

Gelombang yang merambat dari perairan dalam menuju ke arah antara Pulau Kasiak (A) dan Pulau Angso (B), sebagian ada gelombang yang menuju ke arah selatan / Pulau Angso, dan sebagian lagi ada yang terus melaju mendekati pantai / perairan dangkal. Gelombang yang merambat ke arah antara Pulau Angso dan pulau Pulau Tangah (C), sebagian ada yang menuju ke arah selatan / Pulau Tangah, dan sebagian lagi akan terus melaju mendekati pantai. Sedangkan gelombang yang merambat ke arah antara Pulau Tangah dan pulau Pulau Ujung (D), sebagian ada yang menuju ke arah Pulau Ujung dan sebagian lagi terus melaju mendekati pantai

Gelombang datang dengan sudut - 45, perambatan gelombang yang bergerak ke arah selatan akan mengalami pembelokkan serta berusaha tegak lurus dengan garis dasar laut dekat pantai. Pembelokkan ini terjadi karena adanya sudut datang gelombang menuju pantai dengan pendangkalan dasar laut dekat pantai.

Gelombang yang merambat mendekati pantai akan berusaha tegak lurus terhadap garis dasar laut dekat pantai, tetapi belum tentu gelombang datang akan tegak lurus terhadap garis pantai. Ini disebabkan karena garis batimetri tidak selalu sejajar dengan garis pantai. Apabila garis batimetri sejajar dengan garis pantai, maka gelombang datang akan tegak lurus terhadap pantai. Sedangkan garis batimetri tidak sejajar dengan garis pantai, maka gelombang datang akan membentuk sudut terhadap garis pantai.

\section{4 | JURNAL REKAYASA SIPIL}




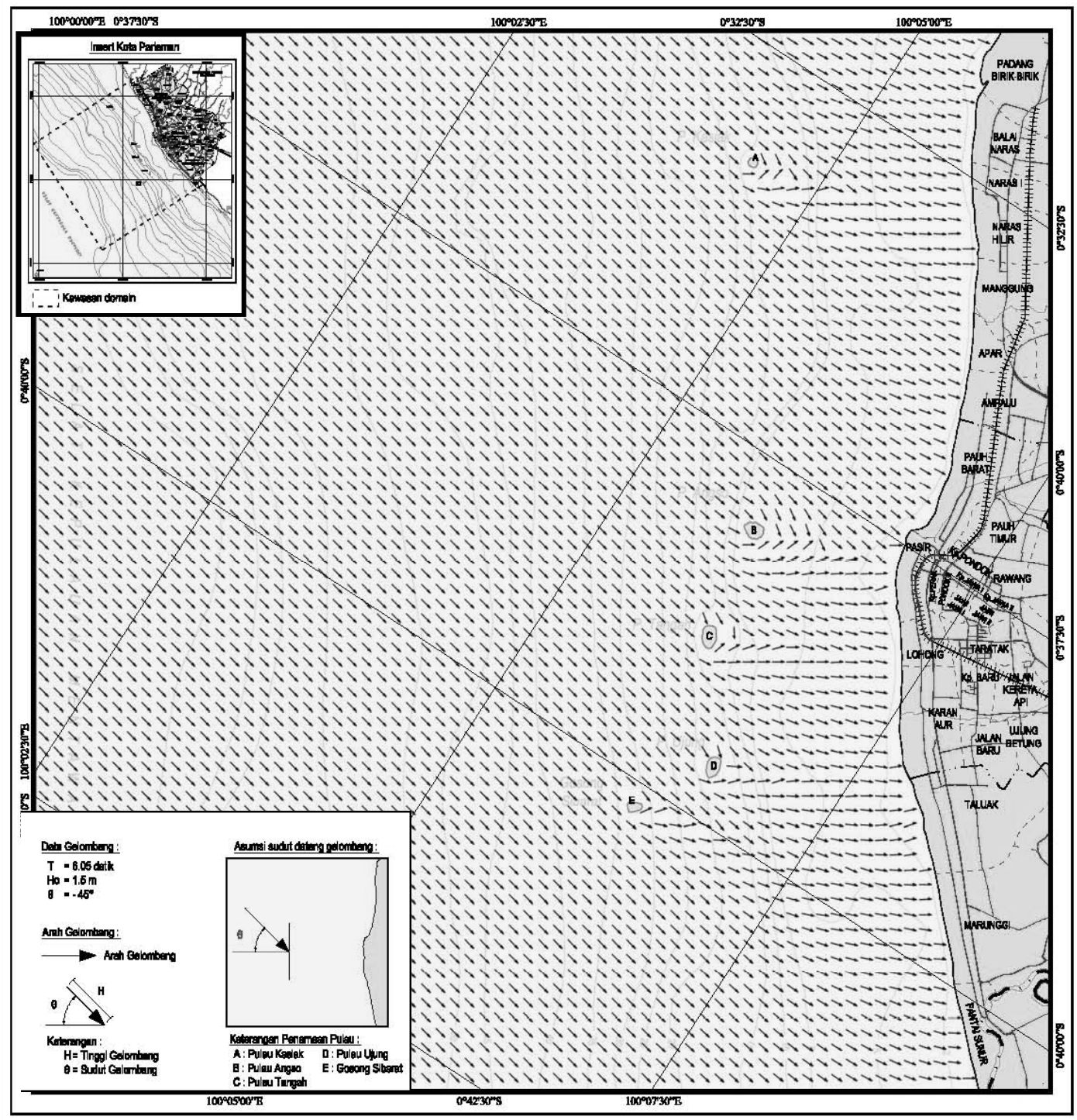

Gambar 2. Pola Penjalaran Gelombang Laut di Perairan Pariaman Pada Sudut Datang Gelombang $-45^{\circ}$

\section{POLA TRANSFORMASI GELOMBANG DENGAN SUDUT DATANG $0^{\circ}$}

Gambar 3. memperlihatkan pola transformasi gelombang dengan sudut datang $0^{\circ}$ atau tegak lurus terhadap garis pantai. Pada Pulau Kasiak (A), gelombang yang melewati samping kiri pulau ini membelok sebesar $120^{\circ}$ ke arah sejajar belakangnya. Gelombang yang melewati samping kanannya mengalami pembelokkan sebesar $133^{\circ}$ ke arah sejajar belakang pulau ini. Di dekat Pulau Angso (B), gelombang yang melewati samping kiri pulau ini mengalami pembelokkan sebesar $138^{\circ} \mathrm{ke}$ arah sejajar belakangnya. Gelombang yang melewati samping kanan pulau ini membelok sebesar $140^{\circ}$ ke arah sejajar belakang pulau ini. Di sekitar Pulau Tangah (C), gelombang yang melewati samping kiri pulau ini mengalami pembelokkan sebesar $128^{\circ}$ ke arah sejajar belakangnya. Gelombang yang melewati samping kanan pulau membelok sebesar $130^{\circ}$ ke arah sejajar belakangnya. Pada Pulau Ujung (D), gelombang yang melewati samping kiri pulau ini mengalami 
pembelokkan sebesar $155^{\circ}$ ke arah sejajar belakangnya. Gelombang yang melewati samping kanan pulau ini mengalami pembelokkan sebesar $146^{\circ}$ ke arah sejajar belakangnya. Dekat Gosong Sibarat (E), gelombang yang melewati samping kiri pulau ini berbelok sebesar $155^{\circ}$ ke arah sejajar belakang pulau. Gelombang yang melewati samping kanan pulau ini mengalami pembelokkan sebesar $142^{\circ}$ ke arah sejajar belakang pulau.

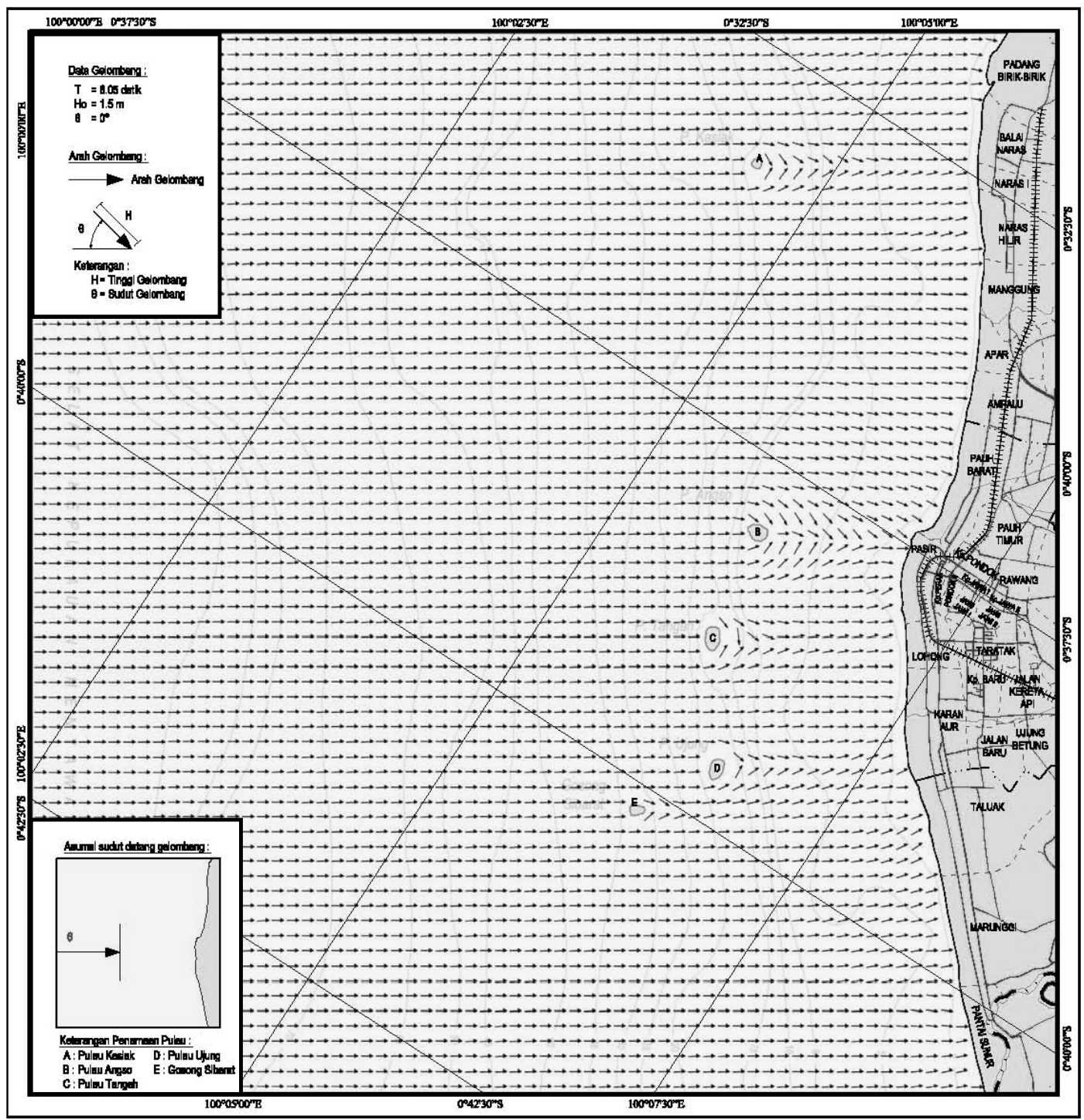

Gambar 3. Pola Penjalaran Gelombang Laut di Perairan Pariaman Pada Sudut Datang Gelombang $0^{\circ}$

\section{POLA TRANSFORMASI GELOMBANG DENGAN SUDUT DATANG45ํำ}

Pada Gambar 4. dapat dilihat pola transformasi gelombang dengan sudut datang $45^{\circ}$ yang terjadi pada pulau-pulau kecil. Pada Pulau Kasiak (A), gelombang yang melewati samping kiri pulau ini berbelok sebesar $148^{\circ}$ ke arah pantai, $98^{\circ}$ ke arah sejajar belakangnya dan gelombang yang melewati samping kanan pulau ini mengalami refraksi sebesar $161^{\circ}$ ke arah sejajar belakangnya.

\section{6 | J URNAL REKAYASA SIPIL}




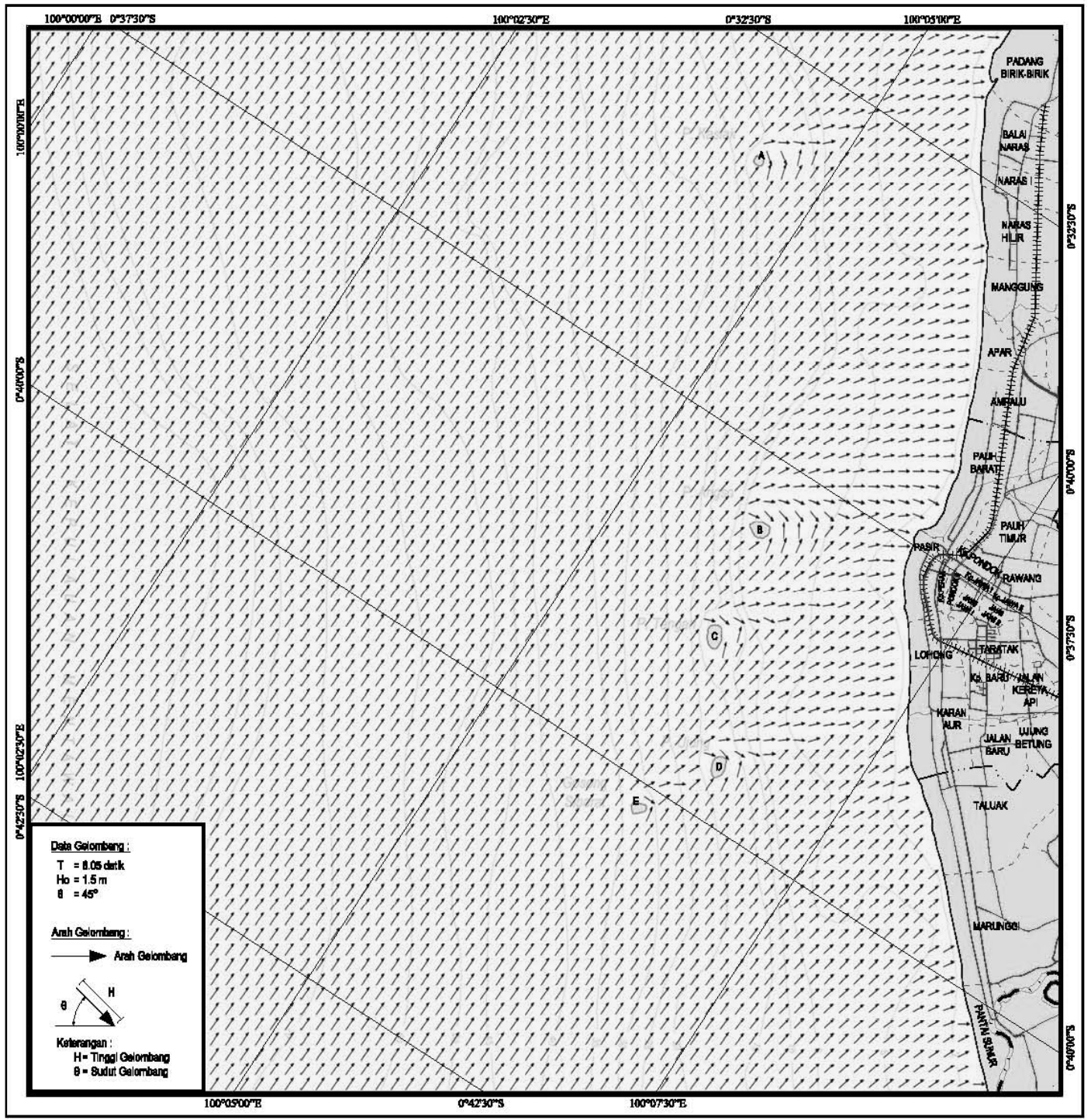

\section{Gambar 4. Pola Penjalaran Gelombang Laut di Perairan Pariaman Pada Sudut Datang Gelombang $45^{\circ}$}

Di Pulau Angso (B), gelombang yang melewati samping kiri pulau ini mengalami pembelokkan sebesar $158^{\circ}$ ke arah pantai, $120^{\circ}$ ke arah sejajar belakangnya, dan gelombang yang melewati samping kanannya mengalami pembelokkan sebesar $155^{\circ}$ ke arah sejajar belakangnya.

Dekat Pulau Tangah (C), gelombang yang melewati samping kirinya mengalami pembelokkan sebesar $155^{\circ}$ ke arah pantai, $113^{\circ}$ ke arah sejajar belakangnya, dan gelombang yang melewati samping kanannya mengalami pembelokkan sebesar $157^{\circ}$ ke arah sejajar belakang pulau ini. Sekitar Pulau Ujung (D), gelombang yang melewati samping kirinya mengalami pembelokkan sebesar $151^{\circ}$ ke arah pantai, $125^{\circ}$ ke arah sejajar belakangnya, dan gelombang yang melewati samping kanannya mengalami pembelokkan sebesar $171^{\circ}$ ke arah sejajar belakangnya. Dekat Gosong Sibarat (E), gelombang yang melewati samping kiri pulau ini mengalami pembelokkan sebesar $153^{\circ}$ ke arah pantai, $117^{\circ}$ ke arah sejajar belakangnya,dan gelombang yang melewati samping kanan pulau akan mengalami pembelokkan sebesar $170^{\circ}$ ke arah sejajar belakangnya. 


\section{KESIMPULAN}

Refraksi dan difraksi di Pantai Pariaman telah disimulasikan menggunakan RCPWave (Regional Coastal Processes Wave Propagation Model) dengan empat program pendukung, yaitu: Grid Generation (untuk mengolah data batimetri dan garis pantai), Dina-Hindcasting (untuk mengolah data angin), WWWL Data (untuk menyusun parameter gelombang), dan WMV (untuk menampilkan vektor gelombang). Kelima program tersebut adalah program yang telah jadi (existing computer softwares).

Domain yang diambil adalah sepanjang Pantai Pariaman, dimulai dari pantai Kelurahan Padang Birik-Birik di utara sampai pantai Kelurahan Pantai Sunur di selatan yang berjarak $14 \mathrm{~km}$ dan kearah lepas pantai sejauh 13,5 km. Dalam domain tersebut terdapat lima buah pulau-pulau kecil, yaitu: Pulau Kasiak, Pulau Angso, Pulau Tangah, Pulau Ujung dan Gosong Sibarat. Data gelombang (periode dan tinggi gelombang) yang digunakan adalah data gelombang yang dibangkitkan oleh angin sepanjang tahun 2010, tetapi sudut datang gelombang dibuat bervariasi yakni sudut $-45^{\circ}, 0^{\circ}$, dan $45^{\circ}$ terhadap garis tegak lurus pantai.

Di perairan yang memiliki pulau-pulau, refraksi dan difraksi gelombang terjadi paling besar di samping kanan pulau-pulau pada sudut datang gelombang $-45^{\circ}$ dengan pembelokkan gelombang sebesar $109^{\circ}$ terjadi di Pulau Tangah, dan di samping kiri pulau-pulau pada sudut datang gelombang $45^{\circ}$ dengan pembelokkan gelombang sebesar $98^{\circ}$ terjadi di Pulau Kasiak. Sedangkan pada sudut datang gelombang $0^{\circ}$, refraksi dan difraksi hampir sama besar pada kedua samping pulau-pulau kecil tersebut. Pada lokasi terjadinya refraksi dan difraksi gelombang menyebabkan tinggi gelombang lebih kecil dari tempat lain. Sementara itu, tinggi gelombang yang besar terjadi di depan semua pulau-pulau kecil tersebut dan dekat garis Pantai Pariaman.

Di perairan yang tidak memiliki pulau-pulau, arah gelombang di dekat sepanjang garis Pantai Pariaman nyaris membentuk sudut tegak lurus dengan garis pantai, kecuali pada pantai di Kelurahan Padang Birik-Birik, Kelurahan Pauh Barat dan Kelurahan Taluak.

\section{UCAPAN TERIMA-KASIH}

Penulis berterima-kasih pada Bapak Ir. Februarman, MT. atas diskusi mengenai materi tulisan ini.

\section{DAFTAR KEPUSTAKAAN}

Baharuddin, dkk, (2009), "Pola Transformasi Gelombang Dengan Menggunakan Model RCPWave Pada Pantai Bau-Bau, Provinsi Sulawesi Tenggara”, E-Jurnal Ilmu dan Tegnologi Kelautan Tropis, Vol. 1, No. 2, PP. 60-71.

CEDAS, (2004a), “NEMOS Sytem Components \& Typical Procedures”, (http:// www.veritechinc.com/products distribution/NEMOStutorial.zip, diaksesMaret 2011)

CEDAS,(2004b), "Regional Coastal Processes Wave Propagation Model Theory And Program Documentation”, (http://www.veritechinc.com/products/cedas/ CEDASmanuals.php, diakses 14 Mei 2011)

Coastal Engineering Resach Center, (1984), “Shore Protection Manual Volume 1”, Washington DC, US Army Coastal Engineering Reseach Center.

Dean, R.G.,and Dalrymple, R.A., (2000),"Water Wave Mechanics for Engineeris and Scientists, Advanced Series on Ocean Engineering Vol 2", New Jersey, World Scientific.

Ebersole, B.A., Cialone, M.A., and Prater, M.D., (1986), "Regional Coastal Processes Numerical Modeling System Report 1 RCPWAVE-A Linear Wave Propagation Model for Engineering

\section{8 | J URNAL REKAYASA SIPIL}


Use”, Technical Report CERC-86-4, US Army Engineer Waterways Experiment Station, Vicksburg, MS.

Faizal, S., (2002), "Studi Karakteristik Refraksi dan Difraksi: Studi kasus pantai Kuta, Tuban Bali", Tesis Master pada Jurusan Teknik Sipil, Institut Teknologi Bandung, Bandung.

Fajra, M., (2011), ”Simulasi Numeris Perubahan Garis Pantai Sasak Akibat Pembangunan Groin”, Tesis Master pada Jurusan Teknik Sipil, Universitas Andalas, Padang.

Hutahean, S., (2008), ”Model Refraksi-Difraksi Gelombang Air Oleh Batimetri”, Jurnal Teknik Sipil, Vol. 15 No. 2 Agustus 2008.

Marine \& Coastal Resources Management Project, (2004), "Proyek Pengelolaan Sumberdaya Pesisir dan Laut", Direktorat Jenderal Kelautan Pesisir dan Pulau-Pulau Kecil - Kementrian Keluatan dan Perikanan, Jakarta.

Riyaldi, S., (2010), "Studi Refraksi Gelombang Di Peraian Dangkal", Skripsi Sarjana pada Jurusan Teknik Kelautan, Institut Teknologi Sepuluh November, Surabaya.

Samulano, I., (2012), "Refraksi dan Difraksi Gelombang Laut di Daerah dekat Pantai Pariaman", Tesis Master pada Jurusan Teknik Sipil, Universitas Andalas.

Taringan,A.P.M., dan Zein, A.S., (2005), ”Analisa Refraksi Gelombang Pada Pantai”, Jurnal Teknik SIMETRIKA, Vol. 4 No. 2, PP. 345-351. 
Refraksi dan Difraksi Gelombang Laut di Daerah Dekat Pantai Pariaman

10 | J URNAL REKAYASA SIPIL 